\title{
Operando NMR characterization of a metal-air battery using a double-compartment cell design
}

\author{
Magali Gauthier ${ }^{* *}$, Minh Hoang Nguyen ${ }^{1}$, Lucie Blondeau, Eddy Foy, Alan Wong \\ Université Paris-Saclay, CEA, CNRS, NIMBE, 91191, Gif-sur-Yvette, France
}

\section{A R T ICLE INFO}

\section{Keywords:}

Operando

In situ

NMR

$\mathrm{Li}-\mathrm{O}_{2}$ battery

Metal-air battery

\begin{abstract}
A B S T R A C T
Applying operando investigations is becoming essential for acquiring fundamental insights into the reaction mechanisms and phenomena at stake in batteries currently under development. The capability of a real-time characterization of the charge/discharge electrochemical pathways and the reactivity of the electrolyte is critical to decipher the underlying chemistries and improve the battery performance. Yet, adapting operandotechniques for new chemistries such as metal-oxygen ( i.e. metal-air) batteries introduces challenges in the cell design due notably to the requirements of an oxygen gas supply at the cathode. Herein a simple operandocell is presented with a two-compartment cylindrical cell design for NMR spectroscopy. The design is discussed and evaluated. Operando ${ }^{7} \mathrm{Li}$ static NMR characterization on a $\mathrm{Li}-\mathrm{O}_{2}$ battery was performed as a proof-of-concept. The productions of $\mathrm{Li}_{2} \mathrm{O}_{2}$, mossy $\mathrm{Li} / \mathrm{Li}$ dendrites and other irreversible parasitic lithium compounds were captured in the charge/discharge processes, demonstrating the capability of tracking the evolution of the anodic and cathodic chemistry in metal-oxygen batteries.
\end{abstract}

1. Introduction

The rechargeable lithium-oxygen $\left(\mathrm{Li}-\mathrm{O}_{2}\right)$ - or lithium-air - battery has recently attracted much attention as a possible high-energy storage alternative to lithium ion battery. Theoretically, it offers a signi ficant high specific energy $\sim 3500 \mathrm{~W} \mathrm{~h} \mathrm{~kg}^{-1}$ in the discharged state (based on the formation oflithium peroxide $\mathrm{Li} \quad{ }_{2} \mathrm{O}_{2}$ as a discharge product from the reaction of $\mathrm{Li}$ ions and $\mathrm{O}_{2}$ gas) by combining the light lithium metal and the natural abundance of oxygen supply as the active materials [ 1-4]. Despite this, the development of $\mathrm{Li}-\mathrm{O}_{2}$ batteries is still at its infancy and has not yet attained its full working potential. Fundamental insights on the reaction pathways during charge and discharge are needed to improve $\mathrm{Li}-\mathrm{O}_{2}$ batteries' performance further. Various advanced in situ (or operandd characterization techniques have played valuable roles for extracting the real-time chemistries in $\mathrm{Li}-\mathrm{O}_{2}$ batteries. For example, in situ microscopy techniques, such as scanning electron microscopy (SEM) [5] or transmission electron microscopy (TEM) [ 6] have unfolded the morphologies of the discharge products ( e.g. $\mathrm{Li}_{2} \mathrm{O}_{2}$ ) and their evolution during cycling; or the use of operandoX-ray diffraction (XRD) for identifying in real-time the crystalline $\mathrm{Li}{ }_{2} \mathrm{O}_{2}$ product [7]. A comprehensive summary of the in situ and operandocharacterizations to probe the interfaces of $\mathrm{Li}-\mathrm{O}_{2}$ batteries can be found in a recent review [ 2].

While the studies above have evidenced the main discharge product as $\mathrm{Li}_{2} \mathrm{O}_{2}$ in non-carbonated based electrolytes such as glymes, other techniques such as X-Ray Photoelectron spectroscopy (XPS) [ 8,9] or differential electrochemical mass spectrometry (DEMS) [ 10-12] demonstrated that parasitic reactions involving electrolyte solutions, $\mathrm{Li}_{2} \mathrm{O}_{2}$ and carbon electrodes occur on charge. Notably, DEMS experiments have shown that the amount of $\mathrm{O}_{2}$ released in charge is lower than what is expected from the $2 \mathrm{e}^{-} / \mathrm{O}_{2}$ ratio for the decomposition of $\mathrm{Li}{ }_{2} \mathrm{O}_{2}$ $[10,12,13]$. In the case of electrolytes based on 1,2-dimethoxyethane (DME), parasitic reactions are observed even at very low potentials in charge and are responsible for the formation of compounds such as $\mathrm{CO}_{2}$, $\mathrm{Li}_{2} \mathrm{CO}_{3}$, lithium-formate and -acetate $[8,9,14,15]$. While these reactions were first ascribed to the reactivity of electrolyte or carbon with superoxides and peroxides, more recently, the critical role of highly reactive singlet ${ }^{1} \mathrm{O}_{2}$ has been brought to attention $[3,4,10,13,16]$. It was found that the singlet ${ }^{1} \mathrm{O}_{2}$ forms from superoxide and peroxide during discharge, and mostly in the early stages of charge at low potential $(<3.5 \mathrm{~V})$. The reactivity of the singlet oxygen with the cell components is

\footnotetext{
* Corresponding author.

** Corresponding author.

E-mail addresses: magali.gauthier@cea.fr (M. Gauthier), alan.wong@cea.fr (A. Wong).

1 Current Address: Institut de Science des Mat ériaux de Mulhouse IS2M - UMR CNRS 7361 - UHA, 15, Rue Jean Starcky, 68057 Mulhouse CEDEX, France
} 
responsible for most parasitic reactions in DME-based electrolytes and explains the formation of parasitic products such as $\mathrm{Li}{ }_{2} \mathrm{CO}_{3}$, Li-formate and -acetate $[3,4,10,17]$.

Ex situ solid-state NMR has been applied to $\mathrm{Li}-\mathrm{O}_{2}$ batteries [ 18-23]. These studies may not provide a realistic view of the battery reactions and may lead to biased data and misinterpretation, particularly knowing the high reactivity of products formed in $\mathrm{Li}-\mathrm{O}_{2}$ batteries. On the contrary, in situ (or operando) NMR has yet to be exploited for $\mathrm{Li}-\mathrm{O}_{2}$ (or metal- $\mathrm{O}_{2}$ in general) studies, although NMR characterization can provide complementary information on amorphous products. This is attributed to the challenges ofincorporating an $\mathrm{O}_{2}$ gas electrode in a working NMR cell or probe.

The current operandoNMR development has been mostly focused on the cell designs, which must adapt to the NMR requirements ( e.g. nonmetallic materials, electrode size) and must present speci fic characteristics for electrochemistry ( e.g. hermetical sealing and good mechanical pressure on the stack). Few designs - such as plastic flat bag, plastic cylindrical Swagelok and plastic capsule - have found successes in Li-ion batteries [24,25]. It is also worth mentioning that aclever NMR cell design based on a plastic jelly-roll cell was recently introduced [ 26], allowing for the first time in situ MAS experiments ( i.e. stop-and-MAS) to be carried out without dismantling the cell. Despite the advancements, these cell designs mostly apply to metal or metal-ion chemistries based on intercalation or insertion and do not allow to monitor more complex battery chemistries. Indeed, performing operandoNMR on metal-oxygen batteries brings additional challenges with the need for oxygen in the cell. There are two options that can be considered: (1) an open-gas system which allows a continuous flow of gas to the porous cathode; or (2) a close system with a gas reservoir directly connected to the porous cathode. A recent design of an open system was patented but has yet been fully explored [ 27]. Herein, we introduce a close system design with a double-compartment cylindrical cell, where one cylinder operates as a gas reservoir and the other hosts the electrodes stack. The advantages of a close-gas design are the easy handling of the operando experiments, without the need to connect to a gas supply, and eliminate the possibility of electrolyte evaporation through gas flow. The drawback is the limited gas supply for the redox reactions. As a proof of concept study, two complete charge/discharge cycles of a $\mathrm{Li}-\mathrm{O}_{2}$ cell were analyzed with operando ${ }^{7}$ Li NMR.

\section{Materials and methods}

\subsection{Description of the electrochemical NMR cell}

The general criteria of an electrochemical NMR cell for operando(and in situ) measurements are as the following: (i) be built from non-metallic materials to eliminate interference with the strong magnetic field; (ii) provide robust airtightness and cell compression for cyclability and durability; (iii) allow for suf ficient electrode mass loading for detection sensitivity, and lastly (iv) the cell geometry must take into account the space available inside the probehead. In addition to these criteria, the cell introduced herein is also complicated by the oxygen gas electrode. As shown in Fig. 1 , we address this by a design of two-joined cylinders. The top large cylinder consists of a gas chamber (with a $655 \mathrm{~mm}^{3}$ ) and a long $9 \mathrm{~mm}$ screw cap connected to a smaller cylinder hosting the electrodes. The benefit of the two compartments design is that it allows a larger volume for the $\mathrm{O}_{2}$ storage to give sufficient $\mathrm{O}_{2}$ for the redox reactions, while the smaller compartment provides greater $B_{1}$ efficiency from the rf coil. Moreover, it ensures a good pressure on the cell stack through the junction of the two compartments, as no suitable spring can be used inside the NMR magnet. A series of gas passages (with a diameter of 0.5 $\mathrm{mm}$ ) are integrated into the connecting screw cap allowing the gas passage from the gas chamber to the electrodes. The gas chamber is sealed with a top cap consisting of $1.2 \mathrm{~mm}$ diameter inlet- and outlet-gas silicone tubings, which are regulated by Omni fit $\mathrm{t}^{\circledR}$ connectors. For a closegas system used in this study, these connectors are closed after the gas injection. However, the design could readily adopt an open system by directly connecting a gas source through the inlet tubing during the operandb measurements. The remote distance from the electrode should prevent electrolyte evaporation by the gas flow. Lastly, the doublecompartment design could, in principle, allow for an independent large volume rf coil around the gas chamber for monitoring the gas content with an individual circuit.

Circular electrodes are hosted at the smaller cylinder center with a stacking arrangement from top to bottom: cathode/separator/anode. Substantially, the cathode ( i.e. gas electrode) is in direct contact with the above gas chamber through the gas passages. The electrodes are compressed by the torque tension generated by two long screw caps, each with a length of $9 \mathrm{~mm}$ and with a pitch thread of $1 \mathrm{~mm}$. A $0.8 \mathrm{~mm} \mathrm{Cu}$-wire - as a current collector - is inserted at both ends of the cell contacting the anode and cathode. The entire cell body is made of polyether ether ketone (PEEK), which has the essential properties for an NMR battery cell: (a)

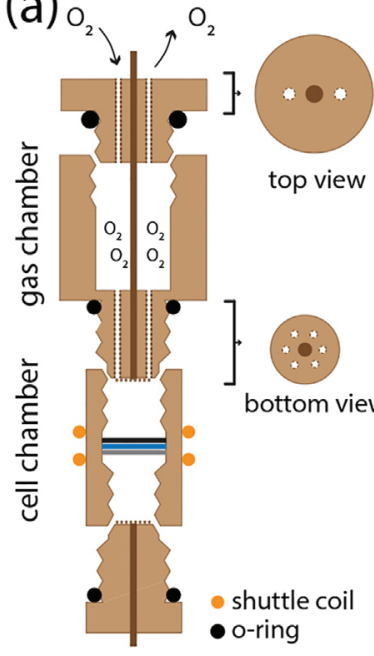

(b)

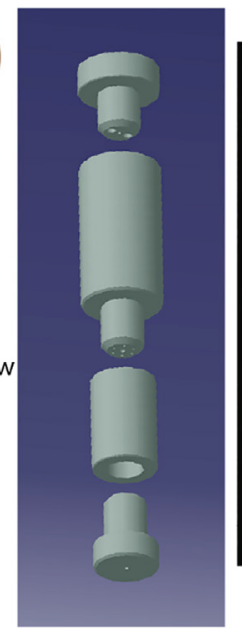

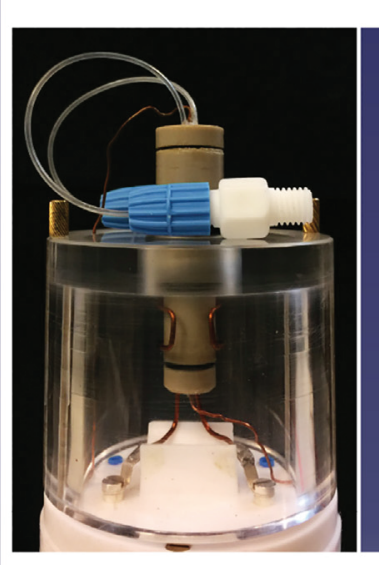

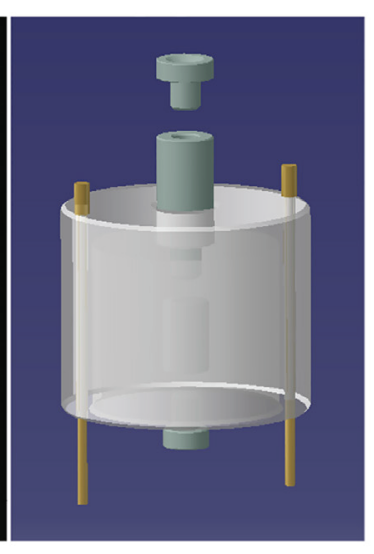

(c)

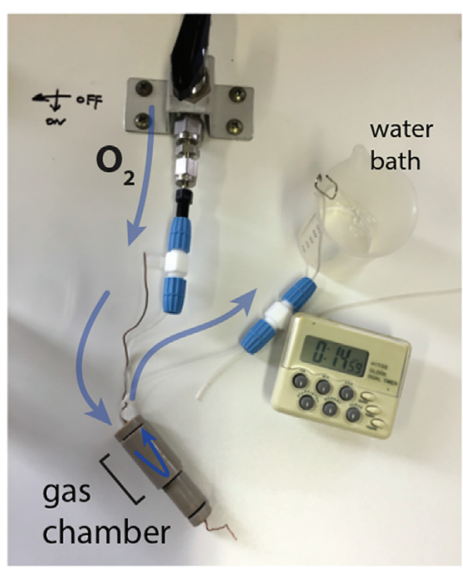

Fig. 1. Design of a $\mathrm{M}-\mathrm{O}_{2}$ cell for operandoNMR experiment. (a) Schematic drawing and model of the double-compartment cylindrical cell, showing the two joint

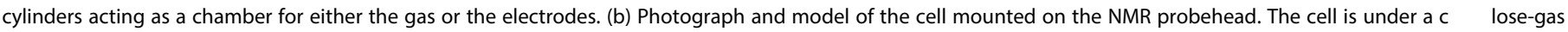
setup. (c) Gas- filling station showing the direction of the gas flow. 
rigid non-conductive material, resistant to mechanical stress [ 28] and chemically inert to metallic lithium and conventional electrolytes used in batteries [25]. Nitrile O-rings ensure hermetic sealing of the cell at all interlocking.

\subsection{Experimental procedure}

\subsubsection{Operando NMR}

${ }^{7}$ Li NMR was carried out on a Bruker Avance II spectrometer operating at a frequency of $194.02 \mathrm{MHz}$ with an 11.75 T NMR magnet with a single channel automatic tuning matching (ATM) NMR probe (NMR Service $\mathrm{GmbH}$ ). The probe allows a rapid automated frequency tuning before each sequential spectral acquisition during the operando measurements. The probe also accommodates the connections for galvanostatic measurements with the potentiostat. A detail description of the ATM and its experimental setup can be found in Ref. [ 29].

The probehead was modi fied with a cylindrical Plexiglas holder supporting the double-compartment cylindrical cell at an upright position (Fig. 1 b). This permits using a saddle coil wrapped closely around the center of the small cylinder containing the electrodes for an optimal sensitivity (maximum filling factor) in the data acquisition. The coil offers a $50 \% \mathrm{~B}_{1}$ homogeneity for the entire detection volume $\left(\sim 900 \mathrm{~mm}{ }^{3}\right)$; a higher \% is expected for the electrode cell $\left(<115 \mathrm{~mm}^{3}\right)$ centered at the coil.

Operando spectra were collected by a series of 32 sequential singlepulse experiments during the $64 \mathrm{~h}$ potential cycling using a single $\pi / 4$ pulse $(4.5 \mu \mathrm{s})$, each with a $5 \mathrm{~s}$ recycle delay, $200 \mathrm{kHz}$ sweep width, and a 1400 scan. Each individual operandospectrum was processed and phased individually in the Bruker Topspin software. The chemical shift was referenced to an external $1 \mathrm{M} \mathrm{LiCl}$ at $0 \mathrm{ppm}$.

The line fittings were carried out with the DMFit program [ 30] using a Gaussian/Lorentzian line shape function. The error bars were deduced by propagating the errors reported for the fitted line width and amplitude. Data processing was done in Excel. Note that the operandoNMR measurements were repeated twice with the same $\mathrm{Li}-\mathrm{O}_{2}$ electrode components using the double-compartment cell. The similar spectral results illustrate the potential of data reproducibility ( Fig. S1).

\subsection{2. $\mathrm{Li}-\mathrm{O}_{2}$ cell assembly and electrochemistry}

The positive electrodes were prepared using either high surface area Carbon black or Carbon Nanotubes (CNTs). Carbon black electrodes were prepared by mixing Carbon Black Super P (99 p\%, Alfa Aesar) with poly(tetra fluoroethylene) binder (PTFE, 60\% wt. dispersion in $\mathrm{H} \quad{ }_{2} \mathrm{O}$, Sigma Aldrich) in a 9:1 ratio with isopropanol. The slurry obtained was then deposited on a $6 \mathrm{~mm}$ diameter copper mesh (80 mesh). For the CNTs cathodes, nanotubes produced by Chemical Vapor Deposition were directly deposited on a copper mesh (6 mm in diameter). For both carbon black and CNT cathodes, the density of carbon was around $1 \mathrm{mg} \mathrm{cm}^{-2}$. In each case, the electrodes were dried in vacuum for $24 \mathrm{~h}$ at $100{ }^{\circ} \mathrm{C}$. Cell assembly was entirely conducted in an Ar- filled glovebox by stacking inside the cell chamber the cathode, two glass micro fiber separators (Whatman GF/A) soaked with electrolyte and a $6 \mathrm{~mm}$ disk oflithium metal $(99.9 \%)$ as the negative electrode. The electrolyte used was $1 \mathrm{M}$ lithium bis(tri fluoromethanesulfonyl)imide (LiTFSI, 99.9\%, Sigma Aldrich) in 1,2-dimethoxyethane (DME, 99.5\%, Acros Organics). Prior to electrolyte's preparation, the LiTFSI lithium salt was dried in vacuum for $24 \mathrm{~h}$ at $100{ }^{\circ} \mathrm{C}$.

After assembly in the glovebox, the $\mathrm{Li}-\mathrm{O}_{2}$ cells were transported to a gas filling station ( Fig. $1 \mathrm{c}$ ), and purged with pure $\mathrm{O}_{2}$ at 0.5 bar for ca. 15 min using Omni fit $\mathrm{t}^{\circledast}$ connectors. After closing the gas-outlet, the inlet was maintained open for $30 \mathrm{~s}$ to build up a positive pressure inside the cell.

Galvanostatic measurements were performed at room temperature using a research-grade potentiostat (Biologic, SP50). The current density was $100 \mathrm{~mA} \mathrm{~g}$ carbon $\left(\mathrm{g}_{\mathrm{c}}^{-1}\right)$ of carbon $\left(\sim 0.1 \mathrm{~mA} \mathrm{~cm}{ }^{-2}\right)$ with a potential range of $2.0-4.0 \mathrm{~V}_{\mathrm{Li}}$. In some cases, the capacity was fixed to 500 or 1000 $\mathrm{mAh} \mathrm{g}_{\mathrm{c}}^{-1}$.

\subsubsection{Ex situ characterization}

XRD and SEM characterizations were performed on discharged electrodes after disassembling the cell. A RU-200B rotating anode X-ray generator using monochromatized Mo radiation ( $\lambda$ 1 $1 / 40.7093 \AA$ ) was used for XRD measurements. Spherical diffraction patterns were acquired using a photo-sensitive plate that was digitized using a scanner. We used the FIT2D [ 31] software to integrate the diffraction patterns. We collected the SEM images using a SEM-FEG Zeiss Ultra 55 model operating at $3 \mathrm{kV}$. To avoid reactivity with air before-and-during the XRD measurement, samples were protected with Kapton tape in the glovebox before the measurement. For SEM, electrodes were stored in argon before being quickly placed ( $<30 \mathrm{~s}$ ) into the microscope to minimize as much as possible air exposure.

\section{Results and discussion}

\subsection{Cycling performance of the NMR cell for $\mathrm{Li}_{-} \mathrm{O}_{2}$ chemistry}

Before performing operandomeasurements on a $\mathrm{Li}-\mathrm{O}_{2}$ system, we first verified the reliability of the $\mathrm{Li}-\mathrm{O}_{2}$ cell chemistry outside the NMR probe in the dedicated cell, which means evaluating the cycling performance and the cell's ability to support $\mathrm{Li}-\mathrm{O}_{2}$ discharge and charge. In particular, we examined the oxygen reduction reaction (ORR) and oxygen evolution reaction (OER) on a carbon nanotubes (CNTs) electrode through galvanostatic cycling. Fig. 2 a shows the potential pro file as a function of capacity (per carbon weight) at a current rate of $100 \mathrm{~mA} \mathrm{~g} \mathrm{c}^{-1}$ with a capacity fixed at $1000 \mathrm{mAh} \mathrm{g}_{\mathrm{c}}^{-1}$ in a $1 \mathrm{M}$ lithium bis(tri fluoromethanesulfonyl) imide (LiTFSI) in 1,2-dimethoxyethane (DME) electrolyte. To evaluate the cell's reproducibility, a similar measurement on carbon black electrode was performed ( Fig. S2) with a capacity limited at $500 \mathrm{mAh} \mathrm{g}{ }_{\mathrm{c}}^{-1}$. A single plateau is observed around $2.5-2.6 \mathrm{~V}_{\mathrm{Li}}$ in discharge for both CNTs (Fig. 2 a) and carbon black electrodes ( Fig. S2b ), in good agreement with literature [ 32-37]. The electrochemical signature of the cell points thus toward the formation of the expected discharge product $\mathrm{Li}{ }_{2} \mathrm{O}_{2}$ following the reaction:

\section{$2 \mathrm{Li}^{\mathrm{p}} \mathrm{p} 2 \mathrm{e}^{-} \mathrm{p} \quad \mathrm{O}_{2} \otimes \quad \mathrm{Li}_{2} \mathrm{O}_{2}$}

The polarization is modest regarding to the thermodynamic potential for the formation of $\mathrm{Li}_{2} \mathrm{O}_{2}\left(\mathrm{E}_{\mathrm{Li} 2 \mathrm{O} 2} 1 / 42.96 \mathrm{~V} \mathrm{Li}\right.$ [1]). The overpotential is also low in charge, with a charge plateau and the end of charge potential around $3.7-3.8 \mathrm{~V}_{\mathrm{Li}}$. This is promising as carbon-based electrodes have usually charging potentials above $4 \mathrm{~V}$ Li $[34,38]$, but in line with the end of charge potentials reported in the literature for CNT-based electrodes (between 3.3 and 4.0 V) [ 35-37]. While the electrochemistry results hint at the formation and decomposition of $\mathrm{Li}_{2} \mathrm{O}_{2}$ during discharge/charge processes, it is yet important to keep in mind that the galvanostatic cycling reflects only the evolution of the potential and the current generated, whether or not the latter results from wanted or unwanted electrochemical processes such as the degradation of the electrolyte or the electrode [13].

In terms of cycling stability, charge and discharge plateaus are maintained for a dozen of cycles at a capacity of $500 \mathrm{mAh} \mathrm{g}{ }_{\mathrm{c}}^{-1}$ for carbon black electrodes ( Fig. S2b ) and at least 4 cycles for the CNTs electrodes at a capacity of $1000 \mathrm{mAh} \mathrm{g} \mathrm{c}_{\mathrm{c}}^{-1}$ (Fig. 2 a). The cyclability is modest as expected for $\mathrm{Li}-\mathrm{O}_{2}$ cells. Globally, the NMR dedicated cell cycling is comparable for the first few cycles to literature and is thus suitable for operando measurements $[3,4,36,37]$. Fig. 2 b shows the ex situ XRD pattern of a CNT cathode at the end of the first discharge. The dominant peak situated at around $12^{\circ}$ refers to the pristine CNT substrate ( Fig. S3). Three other peaks located at 15.0, 16.0 and $18.5{ }^{\circ}(2 \theta)$ correspond to the crystalline $\mathrm{Li}_{2} \mathrm{O}_{2}$ phase, which is the expected discharge product. These $\mathrm{XRD}$ results consequently veri fied that the ideal $\mathrm{Li}-\mathrm{O}_{2}$ electrochemistry is taking place inside our NMR dedicated cell. The morphology of $\mathrm{Li} \quad{ }_{2} \mathrm{O}_{2}$ formed during discharge is highly dependent on the electrode materials and electrolyte, both in fluencing the reaction pathway, from a surface 
(a)

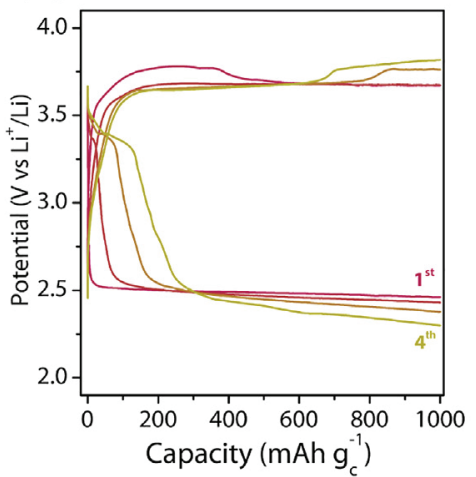

(b)

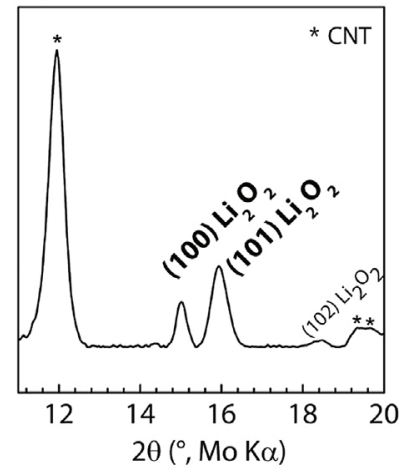

(c)

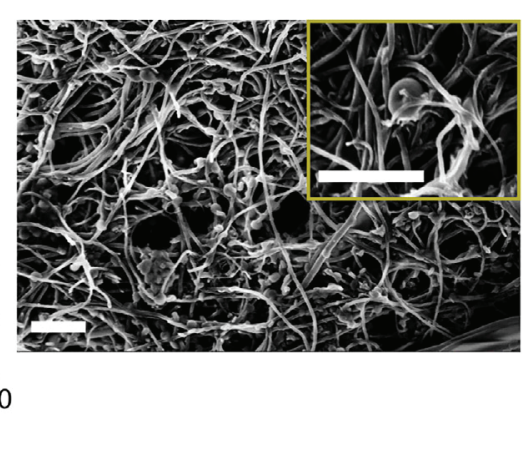

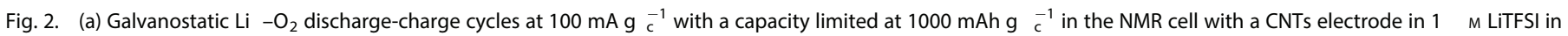
DME. (b) XRD pattern of a CNTs electrode after one discharge at $100 \mathrm{~mA} \mathrm{~g}{ }_{\mathrm{c}}^{-1}$ with a capacity limited at $1000 \mathrm{mAh} \mathrm{g}{ }_{\mathrm{c}}^{-1}$. The peaks are indexed with the 04-013-3506 ICDD card. (c) SEM image of a CNT electrode discharged up to $1000 \mathrm{mAh} \mathrm{g} \quad c_{c}^{-1}$ at $100 \mathrm{~mA} \mathrm{~g}_{\mathrm{c}}^{-1}$ in $1 \mathrm{~m}$ LiTFSI in DME. Scale bar $1 \quad \mu \mathrm{m}$.

dictated reaction to a solution route [ 2-4]. Thus, SEM analysis was performed at the end of the first discharge on both CNT and carbon black electrodes as a complementary analysis to XRD to con firm further the presence of $\mathrm{Li}_{2} \mathrm{O}_{2}$. $\mathrm{Li}_{2} \mathrm{O}_{2}$ is evidenced in both electrodes in the form of toroids, which grow around the carbon nanotubes in CNT electrodes (Fig. 2c) or deposit on the carbon surface in carbon black electrodes (Fig. S2C). The toroid is a characteristic shape of $\mathrm{Li}{ }_{2} \mathrm{O}_{2}$ crystal formation from the disproportionation of $\mathrm{LiO}_{2}$ intermediates formed in the solution route $[33,39]$. Assuredly, the above ex situ results from XRD and SEM have affirmed the double-compartment cylindrical cell 's reliability for generating the ideal $\mathrm{Li}-\mathrm{O}_{2}$ electrochemistry.

\subsection{Operando ${ }^{7} \mathrm{Li} \mathrm{NMR}$ on a $\mathrm{Li}-\mathrm{O}_{2}$ cell}

A close-gas system of a $\mathrm{Li}-\mathrm{O}_{2}$ cell with a CNTs cathode in a LiTFSI/ DME electrolyte was characterized by operando ${ }^{7} \mathrm{Li} \mathrm{NMR}$. The spectral profile obtained at t $1 / 42 \mathrm{~h}$ reveals two main resonances ( Fig. $3 \mathrm{a}$ ), a sharp peak at 2.5 ppm associated to the fast mobile $\mathrm{Li}^{\mathrm{b}}$ in the liquid electrolyte (LiTFSI in DME) and a broad resonance at around $250 \mathrm{ppm}$ related to the Li metal anode, which can be deconvoluted into two peaks at $250 \mathrm{ppm}$ for pristine Li metal and 260 ppm for Li mossy-structures deposited on the bulk metal surface [ 40]. As expected at the beginning of cycling, no Li dendrites are observed at around $270 \mathrm{ppm}$. Here, it should be emphasized that the observed NMR intensity corresponds solely to the microstructures at the metal's surface rather than in its total mass. This is ascribed to the skin effect when a radio frequency (rf) is applied. As such, the measured intensity corresponds only to Li within the skin depth (d) layer, which can be formulated by Ref. [ 41]: $d{ }^{1 / 4}{ }^{q} \rho / \check{\sigma r} \mu_{0} \mu_{\mathrm{r}} \omega_{\mathrm{rf}}$ p where $\rho$

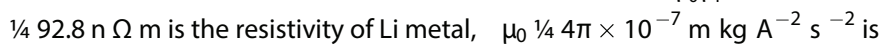
the permeability of the vacuum, $\mu_{\mathrm{r}} 1 / 41.00002$ is the relative permeability of Li metal. In this study at $\omega_{\mathrm{rf}} 1 / 42 \pi \mathbb{2} 93.8 \mathrm{MHz}$, the skin depth layer is calculated to be $11 \mu \mathrm{m}$.

The spectral profile at $t 1 / 440 \mathrm{~h}$ after completing a full cycle has changed noticeability ( Fig. $3 \mathrm{a}$ ), indicating the occurrence of electrochemical processes in the $\mathrm{Li}-\mathrm{O}_{2}$ cell. The spectrum can now be deconvoluted with five different peaks. In particular, a broad resonance centered at 4 ppm is apparent and indicates the presence of slow mobile diamagnetic $\mathrm{Li}^{\mathrm{b}}$ ions. We suspect these species to be the solid products from (electro)chemistry reactions such as $\mathrm{Li}{ }_{2} \mathrm{O}_{2}$ and other parasitic inorganic and organic compounds [ 19,42]. A detail deduction can be found in Fig. S4 and will be further discussed. Exploiting these resolved Li and $\mathrm{Li}^{\mathrm{b}}$ contributions in the spectra, the operandoNMR data set (n $1 / 429$
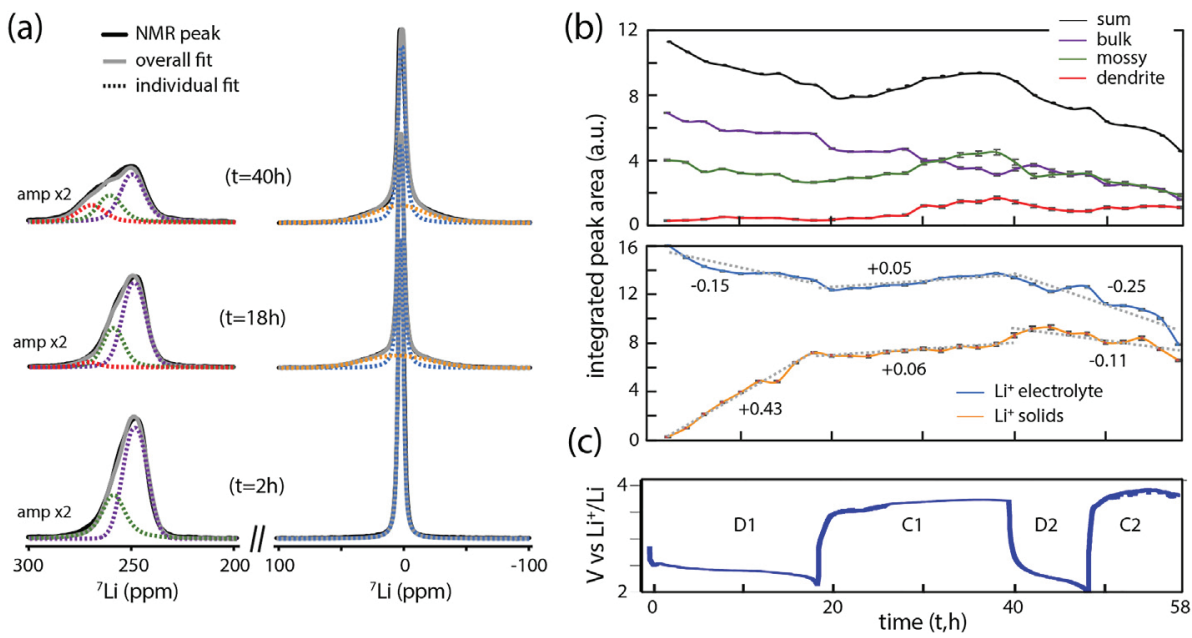

Fig. 3. Operando ${ }^{7} \mathrm{Li}$ NMR spectral results obtained from a close-gas system of a $\mathrm{Li}-\mathrm{O}_{2}$ cell with a CNT electrode in a $1 \mathrm{~m}$ LiTFSI in DME electrolyte. (a) NMR line-fitting of the operandospectra at $t \frac{1}{4} 2$ (beginning of discharge), 18 (end of the first discharge) and $40 \mathrm{~h}$ (end of first charge) reveals the spectral evolution at the different cycling periods. Five fitted Gaussian/ Lorentzian lines are assigned to pristine Li-metal (purple line at $249 \mathrm{ppm}$ ), mossy (green line at 259 ppm) and -dendritic (red line at $271 \mathrm{ppm}$ ) structures, as well as a $\mathrm{Li}^{\mathrm{p}}$ electrolyte (blue line at $2.5 \mathrm{ppm}$ ) and solids (a broad orange line at $4 \mathrm{ppm}$ ). A more in-depth deconvolution of the broad component at $4 \mathrm{ppm}$ can be found in Fig. S4. (b) Time-dependence of the integrated peak areas plotted as a function of the cycling period. The error bars, derived by DMFit [ 30], indicate the misfit. The mean errors across the cycling are $1.4 \%$ for Li-bulk, $2.7 \%$ for Li-mossy, $7.0 \%$ for Li-dendrite, $0.3 \%$ for $\mathrm{Li}$ P electrolyte and $2.0 \%$ for $\mathrm{Li}^{\mathrm{p}}$ solids. In the plot of $\mathrm{Li}^{\mathrm{b}}$ electrolyte and solids lines, the inserted numbers represent the slopes of the tangent lines (dotted grey). (c) The galvanostatic cycling was performed at $100 \mathrm{~mA} \mathrm{~g}{ }_{c}^{-1}$ during the operandomeasurement. D1/C1 and D2/C2 correspond to the discharge and charge of the first and second cycle, respectively. 
spectra) was fitted with five individual Gaussian/Lorentzian (G/L) lines. The fitting was carried out by constraining the chemical shifts for the pristine Li metal and its microstructures (249, 259 and 271 ppm) and allowing an auto-iteration to fit with the line widths and amplitudes of all five resonances, along with the chemical shifts of the two diamagnetic $\mathrm{Li}^{\mathrm{b}}$ peaks $(\sim 2.5$ and $\sim 4 \mathrm{ppm})$. Examples of the fits are shown in Fig. $3 \mathrm{a}$. Each resonance's integrated area was plotted as function of cycling in Fig. 3 b, offering time-resolved quantitative information on the different lithium components in the $\mathrm{Li}-\mathrm{O}_{2}$ cell. The errors were deduced based on the propagation of errors found in the fitted line width and amplitude (reported by DM fit), which are proportional to the area of a G/L line. Overall the errors are small and consistent throughout the operandodata indicating a reliable fitting protocol. Larger errors are found mostly for the mossy and dendrite peaks (with a mean of $2.7 \%$ and $7.0 \%$, respectively). This re flects the difficulty of fitting the extensive overlapping signals. It should be noted that the use of a short recycle delay (5s) in the data acquisitions may hindered the spectral interpretation since different $\mathrm{T}_{1}$ relaxations (long and short) are expected for the different $\mathrm{Li} \quad \mathrm{b}$ species formed during the electrochemistry reactions, which would contribute to the broad signal at $4 \mathrm{ppm}$ and the sharp electrolyte peak at $2.5 \mathrm{ppm}$.

Regardless, the time-dependence peak area of the different $\mathrm{Li} / \mathrm{Li} \quad b$ contributions show discrete trends during the difference cycling processes (Fig. 3 b). Herein, we will discuss chronologically in detail the operandodata following the electrochemical discharge-charge processes.

During the first discharge (D1), we observed a depletion of the Li metal anode (Fig. 3 b). This re flects as expected the Li stripping from the anode ( $\mathrm{Li} \otimes \mathrm{Li}^{\mathrm{b}} \mathrm{p} \mathrm{e}^{-}$). On the contrary, a sudden appearance of a broad resonance at $4 \mathrm{ppm}$ is observed during the discharge process and followed by a gradual rise with a positive linear slope ( $\Delta S \quad 1 / 4$ p 0.43), suggesting a rapid formation of discharge solids containing Li ${ }^{b}$ (Fig. 3 b). Based on the ex situ XRD and SEM results ( Fig. 2) and on the theoretical reaction of $\mathrm{Li}^{\mathrm{b}}$ and $\mathrm{O}_{2}$ to form $\mathrm{Li}_{2} \mathrm{O}_{2}\left(2 \mathrm{Li}^{\mathrm{b}} \mathrm{p} 2 \mathrm{e}^{-} \mathrm{p} \mathrm{O}_{2} \otimes \mathrm{Li}_{2} \mathrm{O}_{2}\right)$, the discharge products could include the relevant $\mathrm{Li}_{2} \mathrm{O}_{2}$ product together with other $\mathrm{Li}^{\mathrm{b}}$ species. Unfortunately, the small shift range for the diamagnetic $\mathrm{Li}^{\mathrm{p}}$ species $(<10 \mathrm{ppm})$ hinders the identi fication of the different compounds. However, one could take advantage of the quadrupolar ${ }^{7} \mathrm{Li}$ by examining the satellite transition signals to distinguish the $\mathrm{Li}^{\mathrm{b}}$ contributions from those with symmetrical environments. A previous ex situ NMR study [ 19] has shown a very distinct ${ }^{7}$ Li static spectral pro file between $\mathrm{Li}_{2} \mathrm{O}_{2}$ and $\mathrm{Li}_{2} \mathrm{CO}_{3}$ : a pair of satellite transition signals are apparent for $\mathrm{Li}_{2} \mathrm{CO}_{3}$ but absent for $\mathrm{Li}_{2} \mathrm{O}_{2}$. This suggests a considerable quadrupolar interaction for the former. On this basis, Fig. S4a shows no apparent (or very small) satellite signals at the end of D1 ( $t \quad 1 / 418 \mathrm{~h}$ ) which could therefore inexplicitly indicates the sole presence of $\mathrm{Li} \quad{ }_{2} \mathrm{O}_{2}$ at the end of the first discharge. However, one should consider that other $\mathrm{Li} \quad \mathrm{b}$ species with insigni ficant ${ }^{7} \mathrm{Li}$ quadrupolar interaction could also contribute to the overall broad signal at $4 \mathrm{ppm}$. Apart from the possible formation of $\mathrm{Li}_{2} \mathrm{O}_{2}$ in $\mathrm{D} 1$, we interestingly observe a decrease in $\mathrm{Li}$ b of the liquid electrolyte ( Fig. 3 b, negative $\Delta S$ of -0.15 ), implying an electrolyte 's consumption through decomposition reactions in discharge. The observed non-linearity may indicate the occurrence of multiple processes, which is in line with the previous studies on DME-based electrolytes that demonstrated that the singlet oxygen and $\mathrm{Li}{ }_{2} \mathrm{O}_{2}$ produced in discharge could react with the glyme electrolyte to produce compounds such as $\mathrm{Li}_{2} \mathrm{CO}_{3}$, Li-acetate and -formate [ 10,14$]$. These compounds can also account for the growth of the broad signal at 4 ppm during D1, but we suspect the extents should be small since no apparent satellite signals are observed ( Fig. S4, t 1/4 $18 \mathrm{~h}$ ) as their quadrupolar interactions are expected to be significant to the line shape $[19,42,43]$.

Unlike D1, the first charge (C1) is marked by a sudden growth of the total Li metal signal ( Fig. 3 b), corresponding to the predicted reverse reaction of Li plating during charge. The Li metal is mostly deposited in the form of mossy Li or Li dendrites ( Fig. 3 b). Singularly, the initial amount of $\mathrm{Li}$ that was present before cycling is not fully recovered, suggesting that not all the lithium that was exchanged for the formation of $\mathrm{Li}_{2} \mathrm{O}_{2}$ in discharge is reversibly going back in charge to the anode. This indirectly indicates that the oxidation of $\mathrm{Li}{ }_{2} \mathrm{O}_{2}$ to $\mathrm{Li}^{\mathrm{p}}$ and $\mathrm{O}_{2}$ is not complete and that some $\mathrm{Li}$ is consumed in parasitic processes. The same conclusion can be drawn from the evolution of the solid phases resonance during $\mathrm{C} 1$ ( Fig. 3 b). If the discharge product $\mathrm{Li}_{2} \mathrm{O}_{2}$ was fully oxidized back to $\mathrm{O}_{2}$ in charge, we should expect a decrease of the broad resonance at $4 \mathrm{ppm}$. Instead, a stable evolution is noticed throughout $\mathrm{C1}$, suggesting irreversible products also formed, countering the decrease of signal related to the reversible $\mathrm{Li}_{2} \mathrm{O}_{2}$ product. These irreversible products could ascribed from the decomposition of electrolyte, discharge products or carbon electrode, and their signals have offset the decreasing of $\mathrm{Li}{ }_{2} \mathrm{O}_{2}$. Noticeably, the low charging voltage of around $3.8 \mathrm{~V}$ for the first charge hints at the release of singlet oxygen from $\mathrm{Li}_{2} \mathrm{O}_{2}$ or $\mathrm{LiO}_{2}$ reaction pathways [ 10]. The reactivity of singlet oxygen ${ }^{1} \mathrm{O}_{2}$ with the cell components such as the electrolyte solvent leads to $\mathrm{Li}$ formate, $\mathrm{Li}$ acetate and $\mathrm{Li} \quad{ }_{2} \mathrm{CO}_{3}$ $[3,4,10,17]$, that can here account for the behavior of the broad signal at $4 \mathrm{ppm}$. As shown in Fig. S4b, this broad signal at t $1 / 440 \mathrm{~h}$ (end of C1) can be deconvoluted with two individual lines, one with a pair of quadrupolar satellite line $\left(C, Q^{1 / 4} 70 \mathrm{kHz}, \eta_{Q}{ }^{1 / 4}\right.$ 0.7) and the other with a single $\mathrm{G} / \mathrm{L}$. The former could be ascribed to $\mathrm{Li}{ }^{\mathrm{b}}$-organic solids $[43,44]$ and $\mathrm{Li}_{2} \mathrm{CO}_{3}$ [19], and the latter to $\mathrm{Li}_{2} \mathrm{O}_{2}$ [19] along with other $\mathrm{Li}^{b}$ species with insigni ficant $\mathrm{C}_{\mathrm{Q}}$. To avoid confusion, as illustrated in Fig. $\mathrm{S} 4$, the single fitted $\mathrm{G} / \mathrm{L}$ line at $4 \mathrm{ppm}$ shown in Fig. 3 and its discussion is ascribed to all $\mathrm{Li}^{\mathrm{b}}$ solid products present in the reactions.

Apart from reactions products from the cathode, note also that the broad signal at $4 \mathrm{ppm}$ may also derived from anode degradation products formed on the Li metal surface. While the XRD and SEM data could not identify these unwanted irreversible products, the operandoNMR highlights some components some decomposition and the non-reversibility of the redox reaction in the $\mathrm{Li}-\mathrm{O}_{2}$ cell in DME electrolyte. Based on the weak reversibility of the Li plating on the anode, we can infer that the degradation products are formed in a quite large amount.

Finally, during the second cycle, as expected from Li metal stripping, the intensity of the metal is depleting in D2 ( Fig. 3 b). Yet only a small increase of the resonance related to solid $\mathrm{Li}^{\mathrm{b}}$-based products occurs, suggesting a deficient production of $\mathrm{Li}_{2} \mathrm{O}_{2}$ from the reduction of $\mathrm{O}_{2}$. It is noteworthy that a rapid degradation of the cell performance begins in $\mathrm{C2}$, indicated by a long flat plateau in charge with a capacity exceeding the one obtained from discharge ( Fig. 3 c). During D2 and C2, the liquid electrolyte resonance decreases signi ficantly, while its linewidth increased by ca. $250 \mathrm{~Hz}$ ( Fig. S5), implying again the presence of electrolyte decomposition and unwanted parasitic reactions. In fact, the second cycle of the operandomeasurement is highly dominated by these decompositions which is similar to what was observed in the literature [14]. This underlines the poor reversibility of the $\mathrm{Li}-\mathrm{O}_{2}$ cell in these electrolyte solutions.

More supporting characterizations ( e.g. ex situ ${ }^{7} \mathrm{Li},{ }^{17} \mathrm{O},{ }^{13} \mathrm{C}$ MAS) are needed to unambiguously elucidate the nature of the degradation products formed here. Regardless, this study exempli fies the discrepancy between the coulometric measurements, suggesting the reversible formation of $\mathrm{Li}_{2} \mathrm{O}_{2}$, and advanced operandoNMR measurements that show here extended degradation of the cell reversibility and formation of parasitic products. This re flects the benefits of using operandotechniques to capture the parasitic reactions in real-time and ultimately decipher the complex electrochemical reactions inside operating $\mathrm{Li}-\mathrm{O}_{2}$ batteries.

\section{Conclusions}

As a proof of concept, this work successfully establishes an operando static ${ }^{7} \mathrm{Li} \mathrm{NMR}$ investigation of the discharge-charge of a $\mathrm{Li} \quad-\mathrm{O}_{2}$ battery. By specifically designing a dedicated cell (double-compartment cylindrical cell) with an oxygen gas reservoir, cycling of a $\mathrm{Li}-\mathrm{O}_{2}$ cell is possible inside the NMR magnet during spectra acquisition. The operandoresults have unveiled the evolution of the lithium anode microstructures, the growth of discharge products on the cathode, and an extensive amount of degradation products. In agreement with previous investigations performed in the literature, these experiments highlight the crucial 
challenges and barriers for ef ficient Li-air batteries, such as the high reactivity of the discharge products and electrolyte, precluding, for now, the commercialization of this technology. Aside from the $\mathrm{Li}-\mathrm{O}_{2}$ chemistry, this study paves the way to operando NMR analysis of alternative promising metal- $\mathrm{O}_{2}$ batteries such as $\mathrm{Na}-\mathrm{O}_{2}, \mathrm{Al}-\mathrm{O}_{2}$ or $\mathrm{Zn}-\mathrm{O}_{2}$ batteries (which could also bene fit from their larger chemical shift and quadrupolar coupling windows), or any electrochemical device involving gas. As such, fuel cells present the common feature to metal-air batteries of providing gas to the cell. The design could be adapted to study fuel cells, providing a continuous flow offuels and oxidants in the cell. This will represent a significant step towards operando NMR offuel cells, only scarcely envisioned due to technical dif ficulties [45,46]. Finally, following the recent advances in in situ MAS NMR [ 26], the cylindrical design with a close-gas system introduced here could potentially be integrated into a spinning cell for in situ MAS NMR (stop-and-MAS) of Li $-\mathrm{O}_{2}$ cells. This would drastically enhance the spectral resolution and bring additional insights for gaining a complete picture of the chemical and electrochemical mechanisms inside an operating cell. For example, it would offer the possibility of probing the enriched ${ }^{17}$ O nucleus [19], which has a much larger span of chemical shift and quadrupolar coupling to decipher the different solid-based products in the $\mathrm{Li}-\mathrm{O}_{2}$ chemistry.

\section{Declaration of competing interest}

The authors declare that they have no known competing financial interests or personal relationships that could have appeared to in fluence the work reported in this paper .

\section{Acknowledgements}

This work was funded by the "bottom-up exploratory program" at CEA. M.H.N. thanks the MOMENTOM project (University Paris-Saclay) for financial support. We are grateful to Dr. Mathieu Pinault (CEA Saclay) for providing CNTs and to Thierry Bernard, Jim Hoarau, M élanie Moskura (CEA Saclay) for their assistance in designing and machining the double-compartment cylindrical cell. We thank Dr. Covadonga LucasTorres (CEA Saclay) for the intensity pro files. We are grateful to the reviewers for their insightful suggestions and efforts toward improving the manuscript.

\section{Appendix A. Supplementary data}

Supplementary data to this article can be found online at https:// doi.org/10.1016/j.ssnmr.2021.101731

\section{References}

[1] A.C. Luntz, B.D. McCloskey, Nonaqueous Li -air batteries: a status report, Chem. Rev. 114 (2014) $11721-11750$, https://doi.org/10.1021/cr500054y

[2] Z. Liang, Q. Zou, Y. Wang, Y.-C. Lu, Recent progress in applying in situ/operando characterization techniques to probe the solid/liquid/gas interfaces of $\mathrm{Li} \quad-\mathrm{O} 2$ batteries, Small Methods 1 (2017) 1700150, https://doi.org/10.1002/ smtd.201700150

[3] W.-J. Kwak, Rosy, D. Sharon, C. Xia, H. Kim, L.R. Johnson, P.G. Bruce, L.F. Nazar, Y.-K. Sun, A.A. Frimer, M. Noked, S.A. Freunberger, D. Aurbach, Lithium -oxygen batteries and related systems: potential, status, and future, Chem. Rev. 120 (2020) 6626-6683, https://doi.org/10.1021/acs.chemrev.9b00609

[4] T. Liu, J.P. Vivek, E.W. Zhao, J. Lei, N. Garcia-Araez, C.P. Grey, Current challenges and routes forward for nonaqueous lithium -air batteries, Chem. Rev. 120 (2020) 6558-6625, https://doi.org/10.1021/acs.chemrev.9b00545

[5] H. Zheng, D. Xiao, X. Li, Y. Liu, Y. Wu, J. Wang, K. Jiang, C. Chen, L. Gu, X. Wei, Y. S. Hu, Q. Chen, H. Li, New insight in understanding oxygen reduction and evolution in solid-state lithium -oxygen batteries using an in situ environmental scanning electron microscope, Nano Lett. 14 (2014) 4245 -4249, https://doi.org/10.1021/ nl500862u.

[6] L. Zhong, R.R. Mitchell, Y. Liu, B.M. Gallant, C.V. Thompson, J.Y. Huang, S.X. Mao, Y. Shao-Horn, In situ transmission electron microscopy observations of electrochemical oxidation of $\mathrm{Li}{ }_{2} \mathrm{O}_{2}$, Nano Lett. 13 (2013) $2209-2214$, https:// doi.org/10.1021/n/400731w

[7] S. Ganapathy, B.D. Adams, G. Stenou, M.S. Anastasaki, K. Goubitz, X.-F. Miao, L.F. Nazar, M. Wagemaker, Nature of $\mathrm{Li} 2 \mathrm{O} 2$ oxidation in a $\mathrm{Li} \quad-\mathrm{O} 2$ battery revealed by operando X-ray diffraction, J. Am. Chem. Soc. (2014), https://doi.org/10.1021/ ja508794r

[8] B. Genorio, J. Staszak-Jirkovsk ý, R.S. Assary, J.G. Connell, D. Strmcnik, C.E. Diesendruck, P.P. Lopes, V.R. Stamenkovic, J.S. Moore, L.A. Curtiss, N.M. Markovic, Superoxide (Electro)Chemistry on well-de fined surfaces in organic environments, J. Phys. Chem. C 120 (2016) 15909 -15914, https://doi.org/ $10.1021 /$ acs.jpcc.5b12230

[9] R. Younesi, M. Hahlin, F. Bj Grefors, P. Johansson, K. Edstr $6 \mathrm{~m}, \mathrm{Li}-\mathrm{O} 2$ battery degradation by lithium peroxide (Li2O2): a model study, Chem. Mater. 25 (2013) 77-84, https://doi.org/10.1021/cm303226g

[10] N. Mahne, B. Schafzahl, C. Leypold, M. Leypold, S. Grumm, A. Leitgeb, G.A. Strohmeier, M. Wilkening, O. Fontaine, D. Kramer, C. Slugovc, S.M. Borisov, S.A. Freunberger, Singlet oxygen generation as a major cause for parasitic reactions during cycling of aprotic lithium -oxygen batteries, Nature Energy 2 (2017) 1 -9, https://doi.org/10.1038/nenergy.2017.36

[11] N. Tsiouvaras, S. Meini, I. Buchberger, H.A. Gasteiger, A novel on-line mass spectrometer design for the study of multiple charging cycles of a $\mathrm{Li}-\mathrm{O} 2$ battery, J. Electrochem. Soc. 160 (2013) A471, https://doi.org/10.1149/2.042303jes

[12] B.D. McCloskey, A. Valery, A.C. Luntz, S.R. Gowda, G.M. Wallraff, J.M. Garcia, T. Mori, L.E. Krupp, Combining accurate $\mathrm{O} 2$ and $\mathrm{Li} 2 \mathrm{O} 2$ assays to separate discharge and charge stability limitations in nonaqueous $\mathrm{Li}-\mathrm{O} 2$ batteries, J. Phys. Chem. Lett. 4 (2013) 2989 -2993, https://doi.org/10.1021/jz401659f

[13] A.C. Luntz, B.D. McCloskey, Li -air batteries: importance of singlet oxygen, Nature Energy 2 (2017) 1 -2, https://doi.org/10.1038/nenergy.2017.56

[14] S.A. Freunberger, Y. Chen, N.E. Drewett, L.J. Hardwick, F. Bard é, P.G. Bruce, The lithium -oxygen battery with ether-based electrolytes, Angew. Chem. Int. Ed. 50 (2011) 8609 -8613, https://doi.org/10.1002/anie.201102357

[15] D. Sharon, V. Etacheri, A. Garsuch, M. Afri, A.A. Frimer, D. Aurbach, On the challenge of electrolyte solutions for $\mathrm{Li}$-air batteries: monitoring oxygen reduction and related reactions in polyether solutions by spectroscopy and EQCM, J. Phys. Chem. Lett. 4 (2013) $127-131$, https://doi.org/10.1021/jz3017842

[16] J. Wandt, P. Jakes, J. Granwehr, H.A. Gasteiger, R.-A. Eichel, Singlet oxygen formation during the charging process of an aprotic lithium -oxygen battery, Angew. Chem. 128 (2016) 7006 -7009, https://doi.org/10.1002/ange.201602142

[17] N. Mahne, S.E. Renfrew, B.D. McCloskey, S.A. Freunberger, Electrochemical oxidation oflithium carbonate generates singlet oxygen, Angew. Chem. Int. Ed. 57 (2018) 5529 -5533, https://doi.org/10.1002/anie.201802277

[18] M. Leskes, A.J. Moore, G.R. Goward, C.P. Grey, Monitoring the electrochemical processes in the lithium -air battery by solid state NMR spectroscopy, J. Phys. Chem C 117 (2013) 26929 -26939, https://doi.org/10.1021/jp410429k

[19] M. Leskes, N.E. Drewett, L.J. Hardwick, P.G. Bruce, G.R. Goward, C.P. Grey, Direct detection of discharge products in lithium -oxygen batteries by solid-state NMR spectroscopy, Angew. Chem. Int. Ed. 51 (2012) 8560 -8563, https://doi.org/ 10.1002/anie.201202183

[20] L.A. Huff, J.L. Rapp, L. Zhu, A.A. Gewirth, Identifying lithium -air battery discharge products through $6 \mathrm{Li}$ solid-state MAS and $1 \mathrm{H}-13 \mathrm{C}$ solution NMR spectroscopy, J. Power Sources 235 (2013) 87 -94, https://doi.org/10.1016/ j.jpowsour.2013.01.158

[21] S. Akabayov Rosy, M. Leskes, M. Noked, Bifunctional role of LiNO3 in Li $\quad-O 2$ batteries: deconvoluting surface and catalytic effects, ACS Appl. Mater. Interfaces 10 (2018) 29622 -29629, https://doi.org/10.1021/acsami.8b10054

[22] T. Liu, M. Leskes, W. Yu, A.J. Moore, L. Zhou, P.M. Bayley, G. Kim, C.P. Grey, Cycling Li-O2 batteries via LiOH formation and decomposition, Science 350 (2015) 530-533, https://doi.org/10.1126/science.aac7730

[23] T. Liu, G. Kim, E. J ónsson, E. Castillo-Martinez, I. Temprano, Y. Shao, J. CarreteroGonzález, R.N. Kerber, C.P. Grey, Understanding LiOH formation in a Li-O2 battery with Lil and H2O additives, ACS Catal. 9 (2019) $66 \quad-77$, https://doi.org/10.1021/ acscatal.8b02783.

[24] O. Pecher, J. Carretero-Gonz ález, K.J. Grif fith, C.P. Grey, Materials ' methods: NMR in battery research, Chem. Mater. 29 (2017) $213 \quad-242$, https://doi.org/10.1021/ acs.chemmater.6b03183

[25] S.A. Kayser, A. Mester, A. Mertens, P. Jakes, R.-A. Eichel, J. Granwehr, Long-run in operando NMR to investigate the evolution and degradation of battery cells, Phys. Chem. Chem. Phys. 20 (2018) 13765 -13776, https://doi.org/10.1039/ C8CP01067F .

[26] A.I. Freytag, A.D. Pauric, S.A. Krachkovskiy, G.R. Goward, In situ magic-angle spinning $7 \mathrm{Li}$ NMR analysis of a full electrochemical lithium-ion battery using a jelly roll cell design, J. Am. Chem. Soc. 141 (2019) $13758 \quad-13761$, https://doi.org/ 10.1021/jacs.9b06885

[27] J.-P. Zheng, A. Shellikeri, Apparatus for In-Situ NMR Spectroscopy of Metal-Air and Metal-free Air Batteries, 2018, US10126366B2. https://patents.google.com/patent US10126366B2/en. (Accessed 18 February 2020).

[28] P.J. Rae, E.N. Brown, E.B. Orler, The mechanical properties of poly(ether-etherketone) (PEEK) with emphasis on the large compressive strain response, Polymer 48 (2007) 598 -615, https://doi.org/10.1016/j.polymer.2006.11.032

[29] O. Pecher, P.M. Bayley, H. Liu, Z. Liu, N.M. Trease, C.P. Grey, Automatic Tuning Matching Cycler (ATMC) in situ NMR spectroscopy as a novel approach for realtime investigations of Li- and Na-ion batteries, J. Magn. Reson. 265 (2016) 200-209, https://doi.org/10.1016/j.jmr.2016.02.008

[30] D. Massiot, F. Fayon, M. Capron, I. King, S.L. Calv é, B. Alonso, J.-O. Durand, B. Bujoli, Z. Gan, G. Hoatson, Modelling one- and two-dimensional solid-state NMR spectra, Magn. Reson. Chem. 40 (2002) 70 -76, https://doi.org/10.1002/mrc.984

[31] A.P. Hammersley, FIT2D: a multi-purpose data reduction, analysis and visualization program, J. Appl. Crystallogr. 49 (2016) $646 \quad-652$, https://doi.org/10.1107/ S1600576716000455 
[32] B.D. McCloskey, D.S. Bethune, R.M. Shelby, T. Mori, R. Schef fler, A. Speidel, M. Sherwood, A.C. Luntz, Limitations in rechargeability of Li-O2 batteries and possible origins, J. Phys. Chem. Lett. 3 (2012) $3043 \quad-3047$, https://doi.org/ $10.1021 / \mathrm{jz} 301359 \mathrm{t}$.

[33] B.M. Gallant, D.G. Kwabi, R.R. Mitchell, J. Zhou, C.V. Thompson, Y. Shao-Horn Influence of Li2O2 morphology on oxygen reduction and evolution kinetics in Li-O2 batteries, Energy Environ. Sci. 6 (2013) $2518 \quad-2528$, https://doi.org/ 10.1039/C3EE40998H.

[34] M.M. Ottakam Thotiyl, S.A. Freunberger, Z. Peng, P.G. Bruce, The carbon electrode in nonaqueous Li-O2 cells, J. Am. Chem. Soc. 135 (2013) $494 \quad-500$, https:// doi.org/10.1021/ja310258x

[35] W.-J. Kwak, K.C. Lau, C.-D. Shin, K. Amine, L.A. Curtiss, Y.-K. Sun, A Mo2C/carbon nanotube composite cathode for lithium -oxygen batteries with high energy efficiency and long cycle life, ACS Nano 9 (2015) 4129 -4137, https://doi.org/ 10.1021/acsnano.5b00267.

[36] J.-W. Jung, J.-S. Jang, T.G. Yun, K.R. Yoon, I.-D. Kim, Three-Dimensional nanofibrous air electrode assembled with carbon nanotubes-bridged hollow $\mathrm{Fe} 2 \mathrm{O} 3$ nanoparticles for high-performance lithium -oxygen batteries, ACS Appl. Mater. Interfaces 10 (2018) 6531 -6540, https://doi.org/10.1021/acsami.7b15421

[37] L. Carbone, P.T. Moro, M. Gobet, S. Munoz, M. Devany, S.G. Greenbaum, J. Hassoun, Enhanced lithium oxygen battery using a glyme electrolyte and carbon nanotubes, ACS Appl. Mater. Interfaces 10 (2018) $16367 \quad-16375$, https://doi.org/ 10.1021/acsami.7b19544

[38] C.V. Amanchukwu, M. Gauthier, T.P. Batcho, C. Symister, Y. Shao-Horn, J.M. D 'Arcy, P.T. Hammond, Evaluation and stability of PEDOT polymer electrodes for Li-O2 batteries, J. Phys. Chem. Lett. 7 (2016) $3770 \quad-3775$, https://doi.org/ 10.1021/acs.jpclett.6b01986
[39] N.B. Aetukuri, B.D. McCloskey, J.M. García, L.E. Krupp, V. Viswanathan, A.C. Luntz, Solvating additives drive solution-mediated electrochemistry and enhance toroid growth in non-aqueous $\mathrm{Li}-\mathrm{O} 2$ batteries, Nat. Chem. 7 (2015) $50-56$, https:// doi.org/10.1038/nchem.2132.

[40] H.J. Chang, A.J. Ilott, N.M. Trease, M. Mohammadi, A. Jerschow, C.P. Grey, Correlating microstructural lithium metal growth with electrolyte salt depletion in lithium batteries using 7Li MRI, J. Am. Chem. Soc. 137 (2015) $15209 \quad-15216$, https://doi.org/10.1021/jacs.5b09385

[41] R. Bhattacharyya, B. Key, H. Chen, A.S. Best, A.F. Hollenkamp, C.P. Grey, In situ NMR observation of the formation of metallic lithium microstructures in lithium batteries, Nat. Mater. 9 (2010) $504 \quad-510$, https://doi.org/10.1038/nmat2764

[42] B.M. Meyer, N. Leifer, S. Sakamoto, S.G. Greenbaum, C.P. Grey, High field multinuclear NMR investigation of the SEl layer in lithium rechargeable batteries, Electrochem. Solid State Lett. 8 (2005) A145 -A148, https://doi.org/10.1149/ 1.1854117

[43] S.V. Bhat, K. Muthukrishnan, J. Ramakrishna, R. Srinivasan, Lithium nuclear magnetic resonance in lithium formate monohydrate, Phys. Status Solidi A11 (1972) K109, https://doi.org/10.1002/pssa.2210110250

[44] S.V. Bhat, A.C. Padmanabhan, R. Srinivasan, Lithium nuclear magnetic resonance in lithium acetate dihydrate, $\mathrm{Li}\left(\mathrm{CH}{ }_{3} \mathrm{COO}\right) .2 \mathrm{H}{ }_{2} \mathrm{O}$, Acta Crystallogr. B30 (1974) 846-848, https://doi.org/10.1107/S056774087400392X

[45] O.H. Han, K.S. Han, C.W. Shin, J. Lee, S.-S. Kim, M.S. Um, H.-I. Joh, S.-K. Kim, H.Y. Ha, Observation of methanol behavior in fuel cells in situ by NMR spectroscopy, Angew. Chem. Int. Ed. 51 (2012) 3842 -3845, https://doi.org/ 10.1002/anie.201108330

[46] A.S. Cattaneo, D.C. Villa, S. Angioni, C. Ferrara, R. Melzi, E. Quartarone, P. Mustarelli, Operando electrochemical NMR microscopy of polymer fuel cells, Energy Environ. Sci. 8 (2015) $2383 \quad-2388$, https://doi.org/10.1039/C5EE01668A 


\section{Supplementary Information}

\section{Operando NMR Characterization of a Metal-Air Battery using a double-compartment cell design}

Magali Gauthier, ${ }^{a,{ }^{*}}$ Minh Hoang Nguyen, ${ }^{a, b}$ Lucie Blondeau, ${ }^{a}$ Eddy Foy, ${ }^{a}$ Alan Wong, ${ }^{a, *}$

a) Université Paris-Saclay, CEA, CNRS, NIMBE, 91191, Gif-sur-Yvette, France

b) Current address: Institut de Science des Matériaux de Mulhouse IS2M - UMR CNRS 7361

- UHA, 15, rue Jean Starcky, 68057 Mulhouse CEDEX, France

Corresponding authors: magali.gauthier@cea.fr (MG); alan.wong@cea.fr (AW)

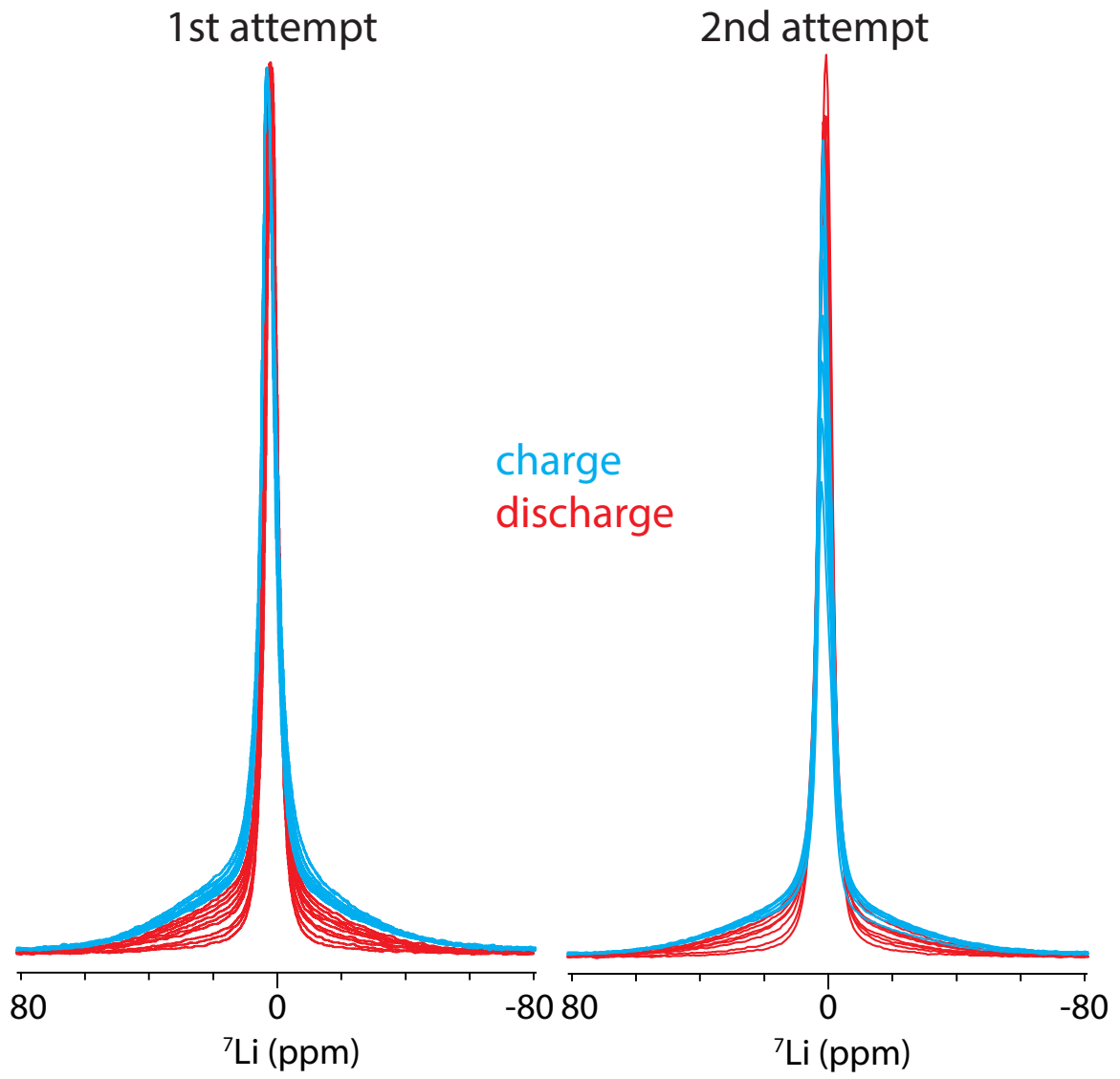

Figure S1. Spectral results of two independent operando ${ }^{7} \mathrm{Li} \mathrm{NMR}$ measurements with two individual Li- $\mathrm{O}_{2}$ cells of the same components: CNTs in $1 \mathrm{~m}$ LiTFSI in DME. Operando spectra of the first complete cycle are shown. The similar spectral evolution of the broad resonance illustrate the reproducibility potential with the double-compartment cell. 
(a)

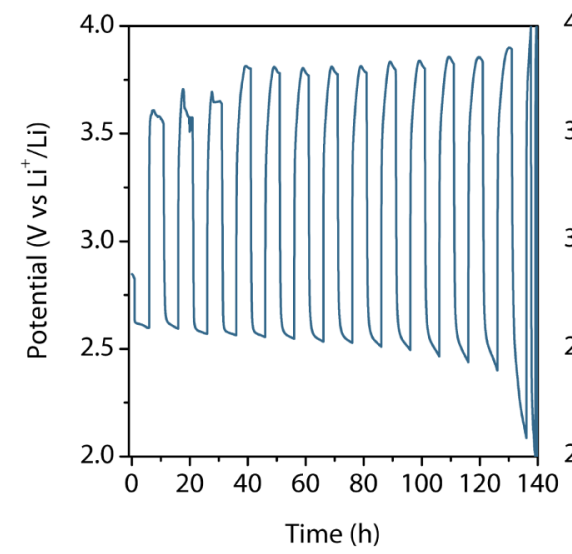

(b)

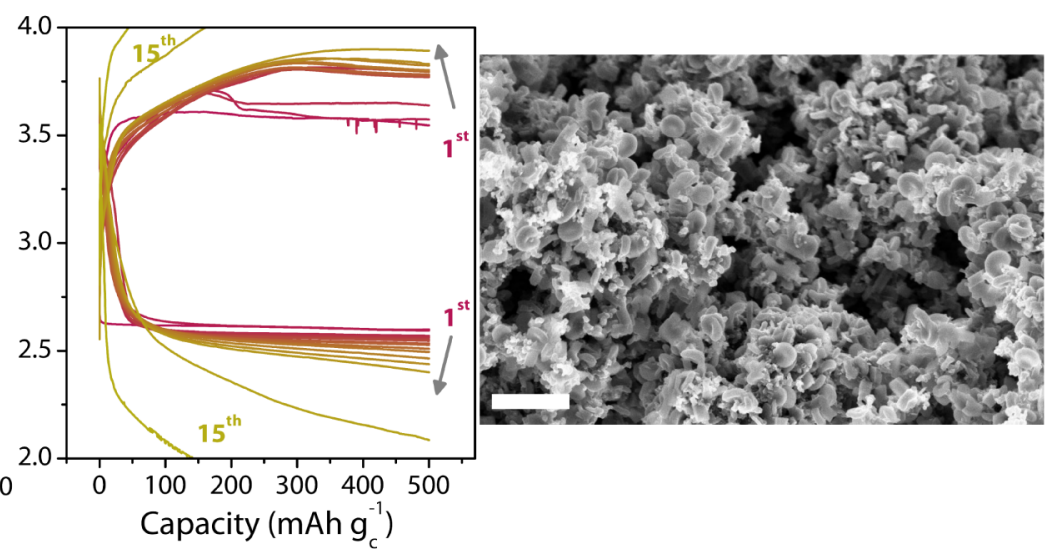

Figure S2. Evolution of the potential as function of (a) time and (b) capacity of a $\mathrm{Li}-\mathrm{O}_{2}$ cell with a carbon black electrode cycled at $100 \mathrm{~mA} \mathrm{gc}^{-1}$ with a capacity limited to $500 \mathrm{mAh} \mathrm{g}_{\mathrm{c}}{ }^{-1}$ in

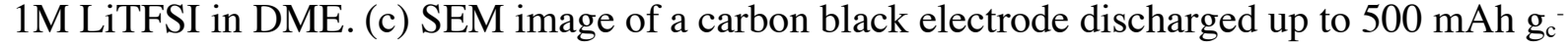
${ }^{1}$ at $100 \mathrm{~mA} \mathrm{~g}_{\mathrm{c}}{ }^{-1}$ in $1 \mathrm{M}$ LiTFSI in DME. Scale bar $1 \mu \mathrm{m}$.

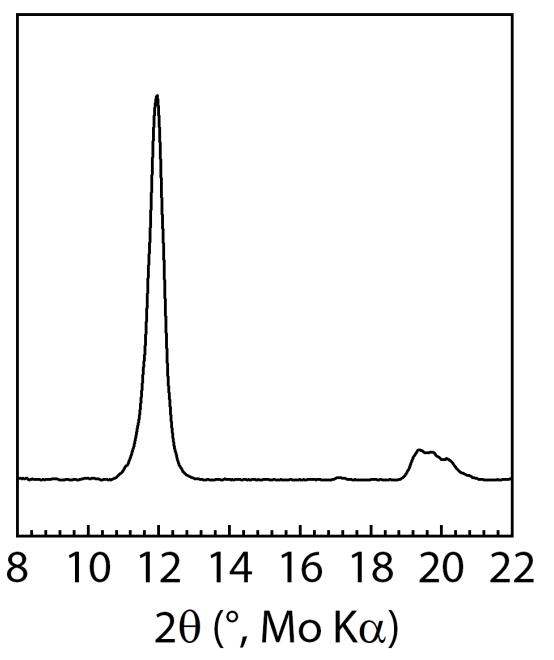

Figure S3. XRD pattern of the pristine CNT electrode. 

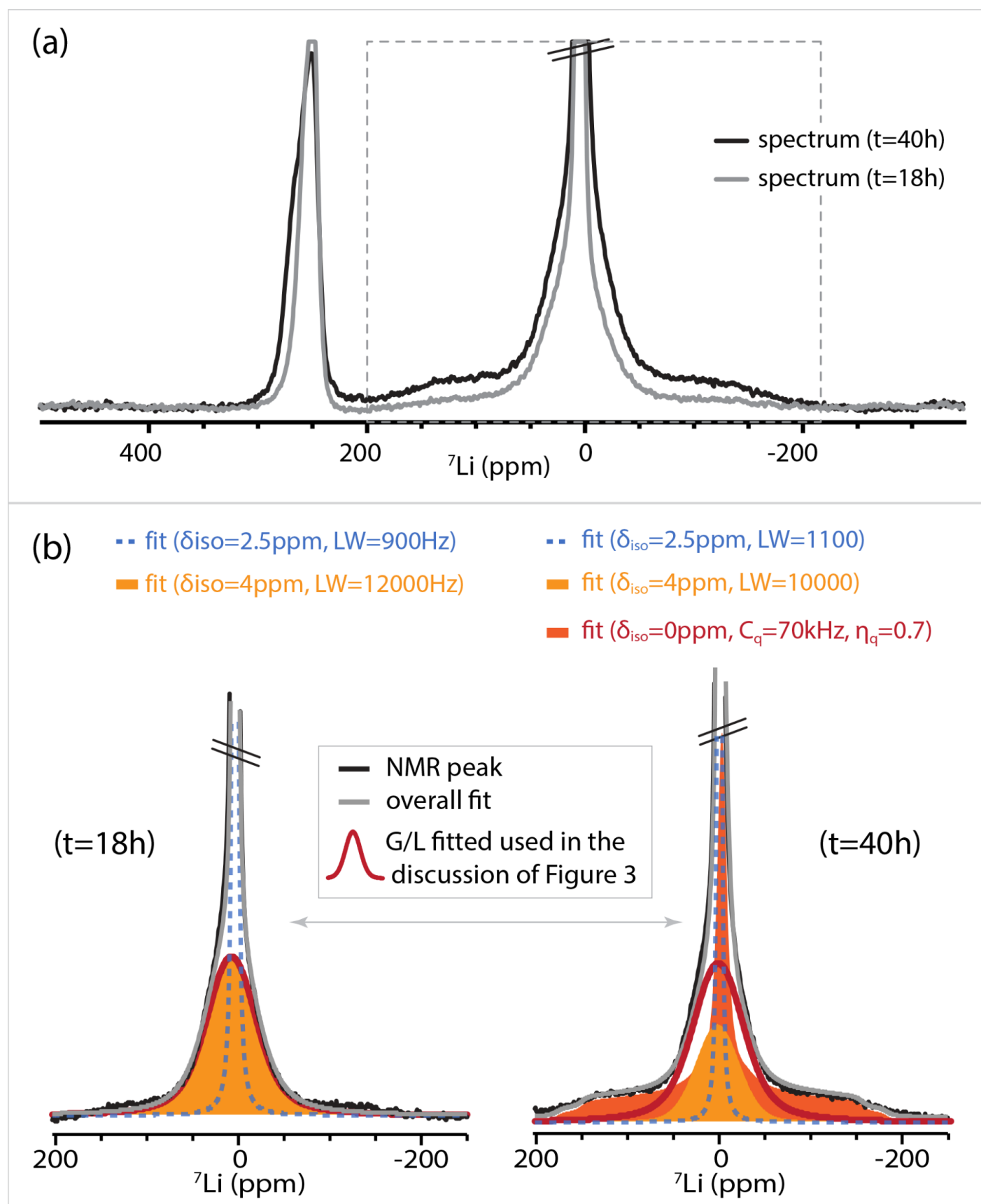

Figure S4. (a) ${ }^{7} \mathrm{Li}$ line shape comparison between the spectrum of $\mathrm{t}=18$ (end of D1) and $40 \mathrm{~h}$ (end of $\mathrm{C1}$ ). The satellite transition signals of the broad resonance (at $4 \mathrm{ppm}$; $\mathrm{Li}^{+}$-solids) are evident at $\mathrm{t}=40 \mathrm{~h}$, but not at $\mathrm{t}=18 \mathrm{~h}$. (b) The broad resonance at $4 \mathrm{ppm}$ was fitted with a single Gaussian/Lorentzian (G/L) line for $\mathrm{t}=18 \mathrm{~h}$; whilst a combination of $\mathrm{G} / \mathrm{L}$ and quadrupolar lines was used for $\mathrm{t}=40 \mathrm{~h}$. The fitting was carried out with Topspin.

Based on figure S4, it is evident that at $40 \mathrm{~h}$ (end of first charge), the broad resonance can be deconvoluted with two individual lines. The quadrupolar line with satellite transitions could be ascribed to the $\mathrm{Li}^{+}$-solid species with significant $\mathrm{C}_{\mathrm{Q}}$. This could include $\mathrm{Li}_{2} \mathrm{CO}_{3}$ [1] and organic compounds such as $\mathrm{Li}$ acetate [2] and formate [3]. On the other hand, the $\mathrm{G} / \mathrm{L}$ line could correspond to $\mathrm{Li}_{2} \mathrm{O}_{2}[1]$.

The red G/L line corresponds to the fit of the broad resonance at 4 ppm shown in Figure 3 and its discussion in the manuscript. Note that for $\mathrm{t}=40 \mathrm{~h}$, the $\mathrm{G} / \mathrm{L}$ fit (red line) accounts for both 
$\mathrm{Li}^{+}$species with insignificant $\mathrm{C}_{\mathrm{Q}}$ (i.e. $\mathrm{Li}_{2} \mathrm{O}_{2}$, etc...) and significant $\mathrm{C}_{\mathrm{Q}}$ (i.e. $\mathrm{Li}_{2} \mathrm{CO}_{3}, \mathrm{Li}^{+}$-organic compounds...).

Indeed, one could carry out the same deconvolution shown in (b) for the entire operando data to offer an in-depth deduction of the different $\mathrm{Li}^{+}$solid species and electrolyte hidden in the broad resonance.

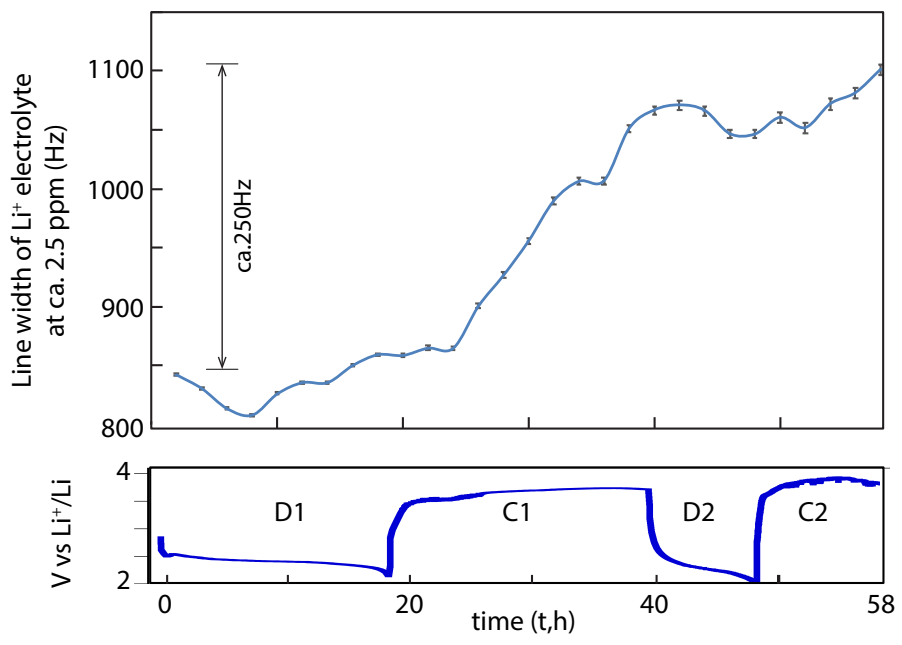

Figure S5. A plot of the line width evolution of the sharp resonance at $\sim 2 \mathrm{ppm}$ ( $\mathrm{Li}^{+}$electrolyte). The line widths were deconvoluted by DMFit.

\section{Reference:}

[1] M. Leskes, N. E. Drewett, L. J. Hardwick, P. G. Bruce, G. R. Goward, C. P. Grey, Angew. Chem. Int. Ed. 51, 34 (2012): 8560-63.

[2] S.V. Bhat, A.C. Padmanabhan, R. Srinivasan, Lithium Nuclear Magnetic Resonance in Lithium Acetate Dihydrate, $\mathrm{Li}\left(\mathrm{CH}_{3} \mathrm{COO}\right) .2 \mathrm{H}_{2} \mathrm{O}$, Acta Cryst. B30 (1974): 846-848.

[3] S.V. Bhat, K. Muthukrishnan, J. Ramakrishna, R. Srinivasan, Lithium Nuclear Magnetic Resonance in Lithium Formate Monohydrate, Phys. Stat. Sol. A11 (1972): K109. 